\title{
Distribution and Targeting of a $\mu$-Opioid Receptor (MOR1) in Brain and Spinal Cord
}

\author{
Ulf Arvidsson, ${ }^{1}$ Maureen Riedl, ${ }^{1}$ Sumita Chakrabarti, ${ }^{2}$ Jang-Hern Lee, ${ }^{1}$ Albert H. Nakano, ${ }^{1}$ Robert J. Dado, \\ Horace H. Loh, ${ }^{2}$ Ping-Yee Law, ${ }^{2}$ Martin W. Wessendorf, ${ }^{1}$ and Robert Elde ${ }^{1}$ \\ 'Department of Cell Biology and Neuroanatomy and '2Department of Pharmacology, University of Minnesota, \\ Minneapolis, Minnesota 55455
}

Opioid receptors regulate neuronal activity by both preand postsynaptic mechanisms. We recently reported that the cloned $\delta$-opioid receptor (DOR1) is primarily targeted to axons, suggesting a presynaptic role. In the present study we have studied the distribution and targeting of another opioid receptor, the $\mu$-opioid receptor (MOR1), by raising anti-peptide antisera to the $\mathrm{C}$-terminal peptide of MOR1. The specificity of the antisera was determined by analysis of transfected cells, Western blots, and immunoisolation studies. Immunohistochemistry showed that MOR1 immunoreactivity was enriched in many brain areas including cerebral cortex, striatum, hippocampus, locus coeruleus, and the superficial laminae of the dorsal horn. Moreover, MOR1-expressing neurons seem to target this receptor preferentially to their somatodendritic domain as determined by double-labeling experiments with MAP2. However, discrete populations of neurons target MOR1 to their axons, including some primary afferent neurons that express DOR1. In many regions enkephalin-containing axons were complementary to MOR1, suggesting by their proximity that enkephalins may be physiologically relevant ligands for this receptor. Thus, these results provide a morphological basis for understanding pre- and postsynaptic functions mediated by MOR1.

[Key words: opiate, postsynaptic, presynaptic, pain, analgesia, antibody production, immunocytochemistry, in situ hybridization, transfection, COS-7, Neuro2a]

Pharmacological, behavioral, and receptor binding studies have suggested the existence of at least three types of opioid receptors in the mammalian brain $-\delta, \mu$, and $\kappa$ (for references, see Simon and Gioannini, 1993). These receptors have specific pharmacological profiles (Lutz and Pfister, 1992) and have been associated with various physiological functions (Herz, 1993). The biosyn-

\footnotetext{
Received Sept. 23, 1994; revised Nov. 28, 1994; accepted Nov. 29, 1994.

We thank Dr. Lei Yu at the Department of Medical and Molecular Genetics, Indiana University School of Medicine, for providing early access to the sequence for the $\mu$-opioid receptor; Dr. Alfred Mansour at the Mental Health Research Institute and Department of Psychiatry, University of Michigan, and Dr. Kim Seroogy at the Department of Anatomy and Neurobiology, University of Kentucky, for helpful advice on in situ hybridization procedures; and Dr. Glenn Giesler, Jr., at Department of Cell Biology and Neuroanatomy, University of Minnesota, for thoughtfully reading and commenting on the manuscript. This study was supported by PHS Grants DA 05466, DA 06299, DA 07339, and DA 00564; Swedish Medical Research Council Project 12X6815; Stiftelsen Wenner-Gren Center; Minnesota Medical Foundation; and the Department of Cell Biology and Neuroanatomy, University of Minnesota

Correspondence should be addressed to Ulf Arvidsson at the above address.

Copyright (c) 1995 Society for Neuroscience 0270-6474/95/153328-14\$05.00/0
}

thetic precursors of each of the opioid peptides contain several possible biologically active products (e.g., met- and leu-enkephalin; dynorphin A1-8, dynorphin A1-13, dynorphin A1-17; $\beta$-endorphin) that exert physiological actions by interacting with opioid receptors (Simon, 1991). Enkephalins from the proenkephalin gene are thought to be ligands for $\delta$-opioid receptors, whereas dynorphins of varied lengths, derived from the prodynorphin gene, have been suggested to be ligands for k-opioid receptors (Corbett et al., 1993). The identity of the endogenous ligand for $\mu$-opioid receptors is uncertain; however, candidates include $\beta$-endorphin (derived from the proopiomelanocortin gene) and the enkephalins.

Binding sites that are thought to represent the $\mu$-opioid receptor are widely distributed throughout the brain and spinal cord (Mansour et al., 1987; Tempel and Zukin, 1987; Mansour and Watson, 1993). High densities of binding are found in regions such as the caudatc-putamen (in striatal patches and in the subcallosal streak), thalamus, interpeduncular nuclei, locus coeruleus, nucleus of the solitary tract, and the dorsal horn of the spinal cord. This distribution of binding sites is consistent with some of the presumed actions of $\mu$-opioid receptors, including those of sensorimotor integration and pain modulation. Following the cloning of a $\delta$-opioid receptor (Evans et al., 1992; Kieffer et al., 1992), a $\mu$-opioid receptor was cloned from rat (MOR1; Chen et al., 1993; Fukuda et al., 1993; Thompson et al., 1993). The anatomical distribution of mRNA coding for this receptor correlates well with the distribution of $\mu$-opioid binding sites (Thompson et al., 1993; Delfs et al., 1994; Mansour et al., 1994). This correlation suggests that $\mu-0-$ pioid receptors are not transported far from their sites of synthesis, making it likely that they are used either as presynaptic receptors in local circuit neurons, as postsynaptic receptors in the dendrites and perikarya of neurons that express the MOR1 transcript, or both.

In recent studies, we found that the cloned $\delta$-opioid receptor (DOR 1 ) is targeted almost exclusively to axons (Dado et al., 1993; Arvidsson et al., 1995), where it most likely functions presynaptically (Glaum et al., 1994). Given the high degree of structural similarity between MOR 1 and DOR1 (55\% homology at the amino acid level), we found it of interest to determine if neurons in various brain regions target MOR 1 in a manner similar to or different from DOR1. We present evidence that MOR 1 is predominantly targeted to the somatodendritic domain, where it most likely functions postsynaptically, although certain groups of neurons direct it to their axons. 


\section{Materials and Methods}

Generation of anti-peptide antisera. Antisera against MOR 1 were produced in six New Zealand White rabbits against a 15-residue peptide (NHQLENLEAETAPLP) corresponding to amino acids 384-398 predicted from the cloned rat MOR1 (Chen et al., 1993; Fukuda et al., 1993; Thompson et al., 1993). The peptide was synthesized using an Applied Biosystems 432A solid-phase peptide synthesizer. The peptide $(10 \mathrm{mg} / \mathrm{ml})$ was conjugated to bovine thyroglobulin (Sigma, St. Louis, MO; $40 \mathrm{mg} / \mathrm{ml}$ ) using $7 \%$ glutaraldehyde (Sigma; $30 \mu \mathrm{l} / \mathrm{ml}$ ). For initial immunizations $1 \mathrm{mg}$ of the peptide-thyroglobulin conjugate was emulsified with an equal volume of Freund's complete adjuvant (Difco, Detroit, MI) and injected in each of six rabbits (551-556). Subsequent immunizations consisted of $0.5 \mathrm{mg}$ of the conjugate emulsified with an equal volume of Freund's incomplete adjuvant administered at 2 week intervals. Serum was obtained 1 week after immunizations, beginning with the third week. Sera from rabbits 551 and 552 were used throughout the study unless otherwise noted.

Construction of epitope-tagged opioid receptor and expression of these receptors in COS-7 and Neuro 2 a cells. MOR1 CDNA was ligated into a pRC/CMV vector (Invitrogen, San Diego, CA) at HindIII sites as described (Chen et al., 1993). The human influenza virus hemagglutinin epitope-tagged MOR1 (hereafter referred to as MORTAG) was constructed by using polymerase chain reaction to insert 39 nucleotides (TACCCATACGATGTGCCCGACTATGCTCTGGTGCCGCGG) immediately $3^{\prime}$ to the initiation ATG. The oligodeoxynucleotide was synthesized by flanking the nucleotide sequence coding for this epitope on both sides with a 15 nucleotide sequence from MOR1 (upstream GCC"ICAGCACCATG; downstream GACAGCAGCACCGGC). Analogous oligodeoxynucleotide sequences for constructing epitopetagged DOR1 and KOR1 were used. As for the downstream primer in the polymerase chain reaction, the SP6 promoter sequence of the $\mathrm{pRC} /$ CMV plasmid was used for generation of the MORTAG fragment. The sequence of DOR 1 between nucleotides 308 and 332, which encompassed the Scal site, was used as downstream primer for DORTAG. The sequence of KOR1 between nucleotides 374 and 393, which encompassed the unique PflMI site, was used as downstream primer for KORTAG. The resulting fragments were subcloned into PCRII plasmid (Invitrogen). For MORTAG, the complete epitope-tagged receptor was excised from PCRII plasmid and subcloned into the pCDNA3 plasmid (Invitrogen) at HindIII and XbaI sites. For DORTAG, the fragment was excised from PCRII with HindIII and ScaI and ligated with pCDNA3 digested with HindIII and XbaI, and a $1.4 \mathrm{~kb}$ DOR 1 fragment isolated by digesting DOR 1 with ScaI and XbaI. Similarly, KORTAG was generated by excising from PCRII with HindIII and PfIMI, subcloned into pCDNA3 plasmid linearized with HindIII and Xbal together with a 1.35 $\mathrm{kb}$ fragment of KOR1 isolated after PfIMI and Xbal digestion. Subsequent plasmids were then isolated with alkaline lysis of bacteria and purified using anion-exchange resins (Qiagen, Chatsworth, CA).

The purified plasmids were then introduced into COS-7 cells using electroporation and into Neuro2a cells by calcium phosphate precipitation method as described by Chen and Okayama (1988). For electroporation, $0.5 \mathrm{ml}$ of COS-7 cells suspended in PBS at concentration of $10^{7}$ cells $/ \mathrm{ml}$ was premixed with $10 \mu \mathrm{g}$ of plasmid DNA. For the stable expression of receptor or epitope-tagged receptor in Neuro2a cells, 30 $\mu \mathrm{g}$ of plasmid DNA solution was added to cells previously seeded in $100 \mathrm{~mm}$ plates of $10^{6}$ cells $/ 10 \mathrm{ml}$ of medium. The Neuro $2 \mathrm{a}$ cells incorporating the plasmids were selected by addition of geneticin (G418, GIBCO, Grand Island, NY) $24 \mathrm{hr}$ later. Colonies formed 10-14 d after the addition of G418 were then picked. The stable expression of the opioid receptor by Neuro2a cells was assessed by ${ }^{3} \mathrm{H}$-diprenorphine binding on intact cells in the presence or absence of $10 \mu \mathrm{M}$ naloxone for $\mu$ - and $\delta$-opioid receptor and $10 \mu \mathrm{M}$ U50,488 for $\kappa$-opioid receptor (Bergsbaken et al., 1993).

Immunoaffinity purification and Western analysis of MORI. Immunoaffinity columns were constructed by cross-linking either IgG from anti-MOR1 (551) or monoclonal 12CA5 (anti-TAG, recognizing the human influenza virus hemagglutinin epitope; Boehringer-Mannheim, Indianapolis, IN) to protein A agarose as suggested by the manufacturer (Pierce, Rockford, II,). Successful immobilization of IgG onto the columns was tested by the ability to retain ${ }^{125} \mathrm{I}-\beta$-endorphin cross-linked to MORI-Neuro2a membranes. Successful cross-linking of anti-TAG to the support agarose was determined by Western blot analysis of proteins isolated by this column from MORTAG-Neuro2a extracts. Cross-linking of ${ }^{125} \mathrm{I}$ - $\beta$-endorphin to the $\mu$-opioid receptor expressed in MOR1-Neu- ro2a cell membranes was carried oul using a modified method of Ko et al. (1992).

For immunoaffinity purification of either wild-type or epitope-tagged MOR l, 2-5 mg of cell membranes was solubilized in $2 \mathrm{ml}$ of solubilizing buffer ( $25 \mathrm{mM}$ HEPES, pH 7.6; $0.1 \mu \mathrm{M}$ PMSF; $10 \mu \mathrm{g} / \mathrm{ml}$ leupeptin; $100 \mu \mathrm{g} / \mathrm{ml}$ bacitracin; $1 \mathrm{~mm}$ EDTA; $1 \%$ Triton X-100) by incubating on ice for $15 \mathrm{~min}$. Afterward, particulates were removed by centrifugation and the supernatant was applied onto a wheat germ lectin column equilibrated with the running buffer ( 25 mM HEPES, pH 7.6 $100 \mathrm{~mm} \mathrm{NaCl} ; 0.1 \%$ Triton X-100). After washing with running buffer, glycoproteins were eluted from the column with $0.5 \mathrm{M} \mathrm{N}$-acetylglucosamine (NAG) in the running buffer.

Immunoblotting was carried out as described (Roerig et al., 1992) with $2 \mathrm{hr}$ incubation with anti-MOR1 (552) or anti-TAG at a dilution of 1:2000 or 1:2500 at room temperature. Horseradish peroxidase-conjugated secondary antibodies, goat anti-rabbit IgG, or goat anti-mouse were used at a 1:5000 dilution. Immunoblots were developed with enhanced chemiluminescence kits (Amersham, Arlington Heights, IL).

Immunohistochemistry. Transfected COS-7 and Neuro2a cells, grown on coverslips, were fixed with $4 \%$ paraformaldehyde and $0.2 \%$ picric acid in $0.1 \mathrm{M}$ phosphate buffer $(\mathrm{pH} 6.9)$ for $1 \mathrm{hr}$. Cells were washed several times in phosphate buffer and then preincubated $1 \%$ normal goat serum, $1 \%$ bovine serum albumin, and $0.3 \%$ Triton $\mathrm{X} 100$ to block nonspecific binding sites. The cells were incubated overnight at $4^{\circ} \mathrm{C}$ with a mixture of rabbit anti-MOR1 (1:5000) and a monoclonal antibody against the human influenza virus hemagglutinin epitope (12CA5, 1:800; Nimar et al., 1983). The staining of cells was detected with a mixture of fluorescein isothiocyanate (1:50) and lissamine rhodamineconjugated antibodies $(1: 50)$.

Male Sprague-Dawley rats (body weight of 150-200 gm, pathogenfree; Harlan, WI) were anesthetized with chloral hydrate $(350 \mathrm{mg} / \mathrm{kg}$ i.p.) and fixed with $4 \%$ paraformaldehyde and $0.2 \%$ picric acid in 0.1 $\mathrm{M}$ phosphate buffer by vascular perfusion as previously described (Wessendorf and Elde, 1985). The spinal cord and brain were dissected and transferred to $10 \%$ sucrose buffer solution for at least $4 \mathrm{hr}$ before cutting. Slide-mounted cryostat sections $(10-14 \mu \mathrm{m})$ and free-floating freezing-microtome sections $(40-50 \mu \mathrm{m})$ were processed for indirect immunofluorescence histochemistry (Coons, 1958). Cryostat sections were incubated with rabbit anti-MORI $(1: 5000)$ for $18-24 \mathrm{hr}$ at $4^{\circ} \mathrm{C}$; free-floating sections $(1: 20,000)$, for $48-96 \mathrm{hr}$. In some instances, double- and triple-labeling procedures were employed (Wessendorf and Elde, 1985; Staines et al., 1988; Wessendorf et al., 1990) using antibodies to enkephalin, DOR1, tyrosine hydroxylase, dopamine $\beta$-hydroxylase, tau, MAP2, synaptophysin, GFAP, or RT97. After being rinsed, the sections were incubated with secondary antisera $(45 \mathrm{~min}$ at room temperature for cryostat sections; overnight at $4^{\circ} \mathrm{C}$ for free-floating sections).

Control sections were incubated with anti-MOR 1 pretrcated with homologous and heterologous peptides. Cross-reactivity controls for both primary and secondary antisera were done according to Wessendorf et al. (1990).

Specimens were examined with a Bio-Rad MRC-1000 Confocal Imaging System (Bio-Rad Microscience Division, Cambridge, MA). For a detailed description of multicolor confocal laser microscopy, see Brelje et al. (1993). The images shown are the results of projecting several optical sections taken at different depths in the section. Images were printed on a Fuji Pictography 3000 color printer at a resolution of 200 pixels/inch.

Preparation of riboprobe for MOR1. An antisense riboprobe for MOR1 was synthesized by linearizing MOR1 cDNA subcloned in the $\mathrm{pRC} / \mathrm{CMV}$ plasmid with the restriction enzyme StuI. Linearized plasmid $(0.5 \mu \mathrm{g})$ was added to the reaction mixlure (Ginal volume of $20 \mu \mathrm{l}$ ) containing transcription buffer (40 mM Tris- $\mathrm{HCl}, \mathrm{pH} 7.5 ; 6 \mathrm{mM} \mathrm{MgCl}_{2}$; $2 \mathrm{~mm}$ spermidine; $10 \mathrm{mM} \mathrm{NaCl}$ ), $10 \mathrm{~mm}$ DTT, $15 \mathrm{U}$ of RNasin, $0.5 \mathrm{~mm}$ each ATP, GTP, and CTP, $12.5 \mathrm{~mm} \mathrm{UTP,} 50 \mu \mathrm{Ci}$ of ${ }^{35} \mathrm{~S}-\mathrm{UTP} \alpha \mathrm{S}$, and 1 $\mathrm{U}$ of Sp6 RNA polymerase. The mixture was incubated at $37^{\circ} \mathrm{C}$ for 60 min followed by the addition $1 \mathrm{U}$ of RQ1 RNase-free DNase to remove the template. After incubating at $37^{\circ} \mathrm{C}$ for an additional $15 \mathrm{~min}$, the mixture was extracted with phenol/chloroform (2:1) once, and nonincorporated radioactivity was separated with RNA spin columns (Boehringer-Mannheim).

In situ hybridization. The methods used for in situ hybridization are similar to those reported elsewhere (Simmons et al., 1989). Tissue for hybridization was obtained from male rats sacrificed by decapitation. Cryostat sections of $14 \mu \mathrm{m}$ thickness were mounted on SuperFrost-Plus 


\section{COS- 7 CELLS TRANSFECTED WITH}

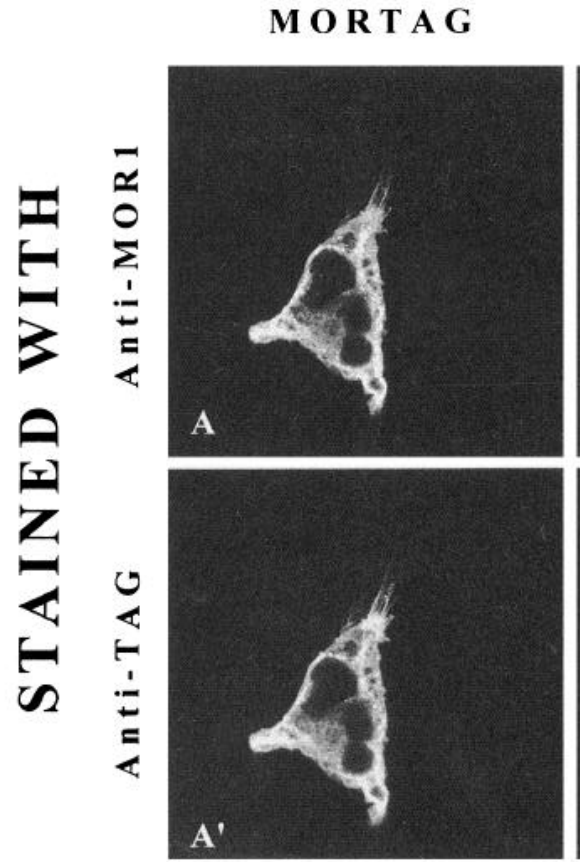

MORTAG ( a bs )
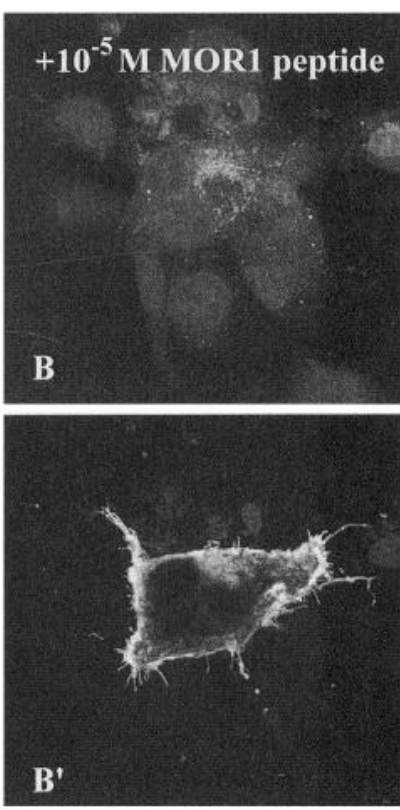

D O R T A G
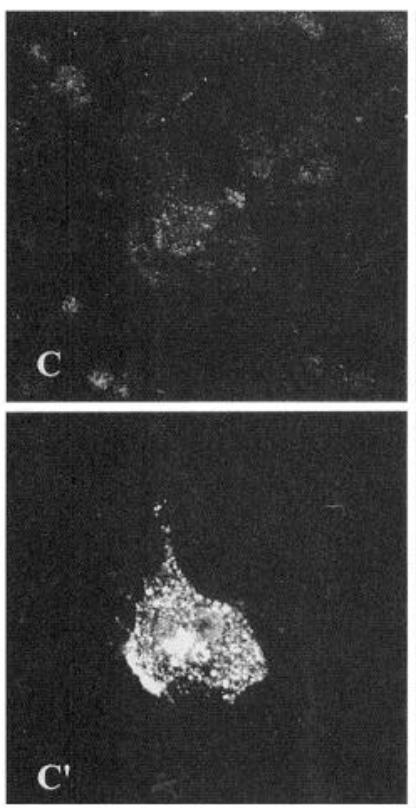

KO R T A G
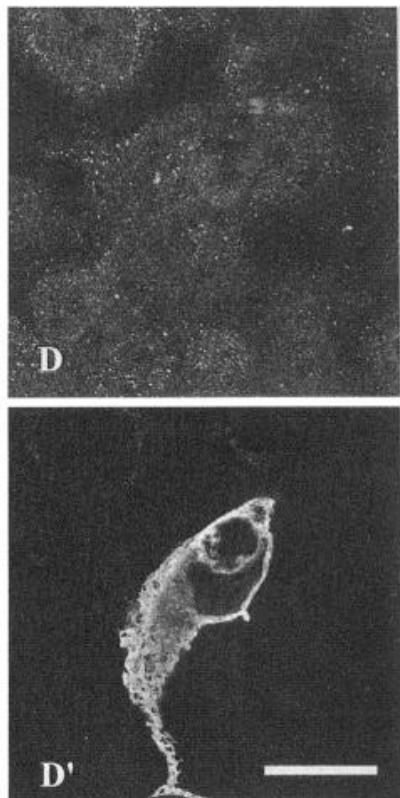

Figure 1. Testing of specificity of MOR1 antiserum on transfected cells: immunofluorescence confocal images of COS-7 cells transfected with MORTAG $\left(A, A^{\prime}, B, B^{\prime}\right)$, an analogous construct of the $\delta$-opioid receptor (DORTAG; $C, C^{\prime}$ ), and an analogous construct of the $\kappa$-opioid receptor (KORTAG; $\left.D, D^{\prime}\right)$ after incubation with anti-MOR1 $(A, C, D)$, anti-MOR1 plus $10^{-5}$ M MOR1 384-398 $(B)$, or anti-TAG $\left(A^{\prime}-D^{\prime}\right)$. Anti-MOR1 stained only COS-7 cells that were transfected with MORTAG rather than DORTAG or KORTAG $(A, C, D)$ and staining was blocked by $10^{-5} \mathrm{M}$ of the peptide against which the antiserum was raised $(B)$. MOR1-ir and TAG-ir coincide in MORTAG-transfected cells $\left(A, A^{\prime}\right)$. DORTAG- and KORTAG-transfected cells revealed intense TAG-ir but no MOR1-ir $\left(C, C^{\prime} ; D, D^{\prime}\right)$. In DORTAG-transfected cells TAG-ir accumulated inside the cell rather than on the plasmalemma $\left(C^{\prime}\right)$. Scale bar, $10 \mu \mathrm{m}$.

slides (Fisher Scientific, Chicago, IL), fixed in freshly made $4 \%$ formaldehyde (10 min at room temperature) and permeabilized with proteinase $\mathrm{K}(20 \mathrm{mg} / \mathrm{ml}$ in $1 \mathrm{M}$ Tris, $\mathrm{pH} 8.0 ; 0.5 \mathrm{M}$ EDTA; $8 \mathrm{~min}$ at room temperature). A second fixation in $4 \%$ paraformaldehyde ( $5 \mathrm{~min}$ at room temperature) was followed by an acetylation procedure using $0.1 \mathrm{M}$ triethanolamine and acetic anhydride (400:1, v/v; $10 \mathrm{~min})$. Sections were then rinsed in distilled water, dehydrated through graded alcohol, and allowed to dry. Sections were incubated with the riboprobe of $2 \times$ $10^{6} \mathrm{cpm} /$ slide in hybridization buffer containing formamide, $20 \times$ hybridization salts, $10 \%$ SDS, Denhardts, DTT, and dextran sulfate at $60^{\circ} \mathrm{C}$ overnight. Washing began with $4 \times \mathrm{SSC}$ (in sodium thiosulfate) at $37^{\circ} \mathrm{C}$, followed by RNase treatment $(20 \mathrm{ml}$ of $0.5 \mathrm{M}$ Tris, $\mathrm{pH} 8.0 ; 2 \mathrm{ml}$ of 0.5 M EDTA, pH $8.0 ; 100 \mathrm{ml}$ of $5 \mathrm{M} \mathrm{NaCl} ; 50 \mu \mathrm{g} / \mathrm{ml} \mathrm{RNase} ; \mathrm{H}_{2} \mathrm{O}$ to 1000 $\mathrm{ml})$ at $45^{\circ} \mathrm{C}$, then subsequent washing in decreasing concentrations of SSC. Sections were rinsed, dehydrated, and apposed to Hyperfilm- $\beta$ max film (Amersham).

\section{Results}

\section{Characterization of MORI antisera}

Antisera generated to the carboxy-terminus of MOR1 were determined to be immunologically selective for MOR 1 by the combined results of several approaches. Central to these analyses was the expression of an epitope-tagged construct of MOR1 (MORTAG) in various cell lines. Immediately $3^{\prime}$ to the start codon of MOR1, a sequence was inserted that codes for the 9 amino acid epitope of the human influenza virus hemagglutinin protein followed by a 4 amino acid thrombin cleavage site (YPYDVPDYALVPR, hereafter referred to collectively as "TAG"). This sequence can be readily detected with a commercially available monoclonal antibody (12CA5) and thus serves to identify independently the tagged receptor. The generation of such chimeric receptors by incorporating an easily localized exogenous epitope has been used for the characterization of adrenergic receptors (von Zastrow and Kobilka, 1992; Keefer and Limbird, 1993) as well as for a substance P receptor (Vigna et al., 1994).

\section{Immunofluorescent localization of epitope-tagged opioid receptors}

In COS-7 cells electroporated with MORI cDNA, MOR1 immunoreactivity (-ir) was prominent in the plasmalemma, but was also observed in subcellular compartments that resembled the endoplasmic reticulum, Golgi apparatus, and vesicle-like structures (not shown). A similar staining pattern was observed in cells transfected with MORTAG (Fig. 1A). In both cases, a similar fraction $(\sim 5 \%)$ of the cells on a given coverslip expressed detectable MOR1-ir. In preparations transfected with MORTAG, only cells that expressed MOR1-ir also expressed TAG-ir, and the subcellular pattern of staining was identical (Fig. 1 $A, A^{\prime}$ ). Pretreatment of anti-MOR 1 with the cognate peptide prevented staining of MORTAG-transfected cells although the same cells were still vividly stained by anti-TAG; Fig. $1 B, B^{\prime}$ ). These data strongly suggest that anti-MOR 1 recognizes MOR1 per se. Staining obtained with anti-MOR 1 was determined to be selective with respect to other members of the opioid receptor family, since COS-7 cells transfected with epitope-tagged constructs encoding $\delta$ - or $\kappa$-opioid receptors were not stained (Fig. $\left.1 C, C^{\prime}, D, D^{\prime}\right)$. 


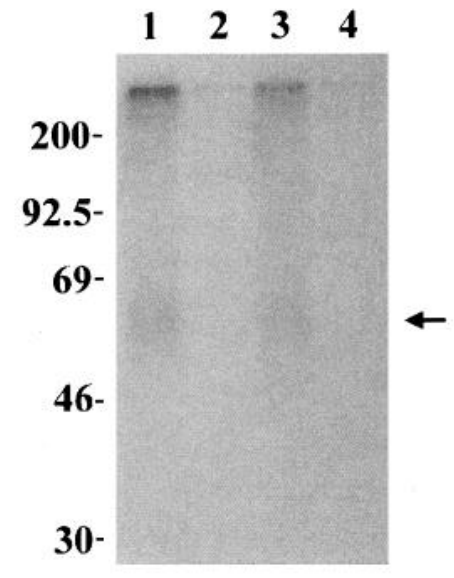

Figure 2. Immunoisolation of a ${ }^{125} \mathrm{I}-\beta$-endorphin/receptor complex: autoradiogram of membrane proteins derived from MOR1-Neuro2a cells cross-linked to ${ }^{125} \mathrm{I}$ - $\beta$-endorphin in the absence (lanes 1 and 3 ) and presence (lanes 2 and 4 ) of $100 \mathrm{~nm}$ DAMGO. Partially purified membrane extracts (over a wheat germ lectin column) revealed a diffuse band at 63-67 kDa (lane 1). Labeling was prevented by DAMGO (lane 2). The same diffuse band was seen after further purification using an immunoaffinity column constructed with anti-MOR1 (551; lane 3$)$ but was absent in the presence of DAMGO (lane 4).

\section{Immunoisolation of a ${ }^{125} I$ - $\beta$-endorphin/receptor complex}

Earlier cross-linking studies with ${ }^{125} \mathrm{I}-\beta$-endorphin and rat brain membranes indicated that the $\mu$-opioid receptor has mass of 65 kDa (Howard et al., 1985). As shown in Figure 2, membrane proteins from Neuro2a cells transfected with MOR1 that were cross-linked with ${ }^{125} \mathrm{I}-\beta$-endorphin and eluted from a wheat germ lectin column with NAG revealed a diffuse band with a molecular mass of 63-67 kDa (Fig. 2, lane 1). This labeling was pre- vented by the addition of DAMGO, a $\mu$-opioid-selective ligand (Fig. 2, lane 2). Further purification of this ${ }^{125} \mathrm{I}-\beta$-endorphinlabeled protein complex using an immunoaffinity column constructed with an MOR1 antiserum (551) demonstrated an identical pattern of labeling (Fig. 2, lanes 3,4). Thus, the fraction retained in the immunoaffinity column was labeled by ${ }^{125} \mathrm{I}-\beta$ endorphin. Together, these data suggest that the MOR1 antisera recognize the ${ }^{125} I-\beta$-endorphin/ $\mu$-opioid receptor complex.

\section{Western analysis}

Membrane proteins derived from the Neuro2a cell line (Fig. 3, lanes 1), MOR1-Neuro2a (lanes 2, 4), MORTAG-Neuro2a (lanes 3, 5, 6), and rat brain (lanes 7) were partially purified using a wheat germ lectin column, separated by SDS-PAGE, blotted onto nitrocellulose, and probed with either the MOR1 antisera (552; Fig. 3A) or anti-TAG (Fig. 3B).

Membrane proteins isolated from cells transfected with MOR1 and eluted from a wheat germ lectin column using NAG contained several closely migrating bands with relative molecular weights of $67-72 \mathrm{kDa}$ that were stained by anti-MOR 1 (552; Fig. $3 A$, lane 2) but not by anti-TAG (Fig. 3B, lane 2). Similar bands were apparent in NAG eluates of membrane proteins from cells transfected with MORTAG when probed with either anti-MOR1 (552; Fig. 3A, lane 3) or anti-TAG (Fig. 3B, lane 3). After staining for MOR1, similar bands were observed in eluates from an immunoaffinity column constructed using the IgG fraction from an antiserum to MOR1 (551; Fig. 3A, lanes 4 and 5, transfected with MOR1 and MORTAG, respectively). The equivalent lanes probed with anti-TAG revealed no staining in the 67-72 kDa range for MOR1-transfected cells (Fig. 3B, lane 4), but staining was apparent in MORTAG-transfected cells (Fig. 3B, lane 5). To test whether anti-MOR1 and anti-TAG recognized the same proteins, we stained membrane proteins

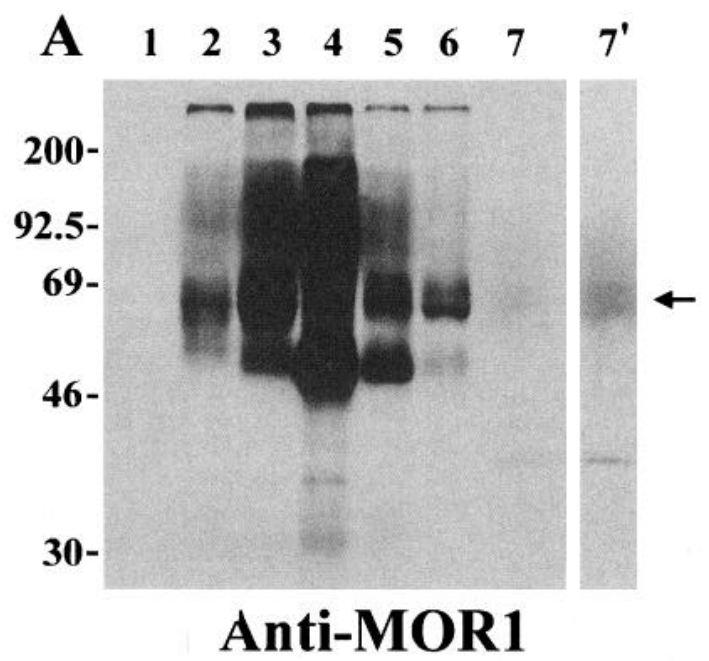

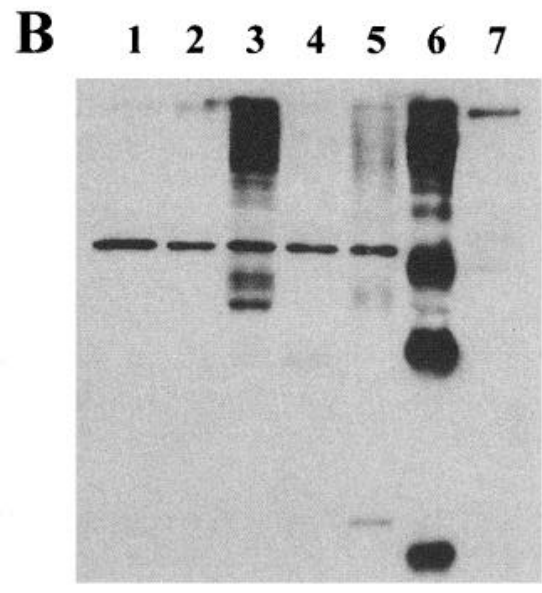

Anti-TAG

Figure 3. Immunolabeling of membrane proteins with anti-MOR1 and anti-TAG. Western analysis of partially purified extracts from Neuro2a cells stably expressing either MOR1 or MORTAG is shown using anti-MOR1 $(552 ; A)$ and anti-TAG (monoclonal 12CA5; $B$ ). In both $A$ and $B$, lanes $1-3$ and 7 represent membrane preparations partially purified over a wheat germ lectin column; lanes 4 and 5 represent preparations partially purified by column chromatography first using wheat germ lectin and second using an immunoaffinity column constructed with anti-MOR 1 (551); lanes 6 are identical to lanes 4 and 5 except that it was immunoaffinity purified using a column constructed with anti-TAG. No staining was seen in membrane preparations from nontransfected cells $(A, B$, lanes 1$)$. Membranes from MOR1-Neuro2a cells contained proteins with a molecular weight of 67-72 kDa that were stained using anti-MOR1 (A, lanes 2 and 4 ) but not using anti-TAG (B, lanes 2 and 4$)$. Similar bands from MORTAG-Neuro2a cells were stained using both anti-MOR1 (A, lanes 3, 5, and 6 ) and anti-TAG (B, lanes 3 and 5$)$. Lanes 6 were not informative due to leeching of anti-TAG from the affinity support $(B$, lane 6$)$. Rat brain membrane preparations contained protein(s) with similar molecular weight that could be stained using anti-MOR1 ( $A$, lane 7 ; digitally enhanced in lane $\left.7^{\prime}\right)$ but not with anti-TAG $(B$, lane 7$)$. The amount of protein loaded from Neuro2a extracts was equivalent to $0.5 \mathrm{mg}$ of membrane proteins. Rat brain membrane was loaded at an equivalent of $6 \mathrm{mg}$ of the membrane protein. 
isolated from cells transfected with MORTAG and those that were eluted from an immunoaffinity support constructed with anti-TAG. Anti-MORl stained proteins with molecular weight of $67-72 \mathrm{kDa}$ in this eluate (Fig. $3 A$, lane 6), suggesting that anti-MOR 1 and anti-TAG recognized the same protein(s). As expected, neither anti-MOR 1 nor anti-TAG recognized proteins in nontransfected Neuro2a cells (Fig. $3 A, B$, lanes 1). Proteins extracted from rat brain membranes stained by anti-MORI gave results similar to those seen in transfected cell preparations [Fig. $3 \Lambda$, lanes $7,7^{\prime}$ (digital enhancement of lane 7)].

\section{Absorption controls and epitope mapping of anti-MORI}

Absorption controls for anti-MOR 1 were performed in brain tissue using the peptide used for immunization (MOR1 384-398, NHQLENLEAETAPLP; that is, the carboxy-terminal 15 amino acids of the receptor) as well as a series of shorter fragments from within this sequence. Staining in brain was abolished for anti-MOR 1 (551, 552, and 556) preabsorbed with $10^{-7} \mathrm{M}$ or higher concentration of MOR1 384-398 (Fig. 4C). Absorption with peptides corresponding to amino acids 384-390 (NHQLENL) and 388-393 (ENLEAE) did not block the staining at $10^{-3} \mathrm{M}$; however, a peptide representing amino acids $391-398$ (EAETAPLP) blocked the staining at concentrations as low as $10^{-6} \mathrm{M}$ (not shown). Thus, the epitope for anti-MOR 1 seems to be within the last 5-8 amino acids of the receptor.

\section{Cellular distribution of MORI}

A large number of MOR1-ir cell bodies and their processes were stained in brain. To analyze the compartmentalization of MOR 1 in neurons, double-immunolabeling experiments were performed using anti-MORl and specific markers for each compartment. Antibodies to tau and synaptophysin (p38) were used to mark axons, whereas antibodies to MAP2 were used to mark dendrites. In addition, antibodies to GFAP were used as a marker for glia. Throughout the brain and spinal cord, MORl-ir was primarily localized in the somatodendritic domain of neurons, although instances of MOR1 staining in axons were also found. No MORI staining associated with glia was observed.

Different cellular and subcellular patterns of MOR 1-ir were observed in neurons in the brain and spinal cord. In one group of neurons (including cortical neurons in laminae II and III and in the hippocampus), MOR1-ir was seen as small puncta within the cytoplasm of perikarya and within processes (Fig. $4 A, B$ ). These puncta could possibly represent vesicles transporting the receptor to or from its target (in the text these puncta will also be referred to as vesicle-like structures). Labeling could also sometimes be seen in the plasmalemma of these neurons. In a second group of neurons (including cells in the superficial dorsal horn of the spinal cord) MOR 1-ir was seen mainly in the plasmalemma of perikarya but also extended into the primary dendrites (Fig. 4D). Labeling of plasmalemma was in some cases not continuous; instead labeling was concentrated in small clusters (Fig. 4E). In a third group of neurons MOR1-ir was observed within axons (including fasciculus retroflexus and the accessory medial optic tract; Fig. $4 F$ ). In a few axons, MOR1ir could be found in vesicle-like structures within varicosities as well as in intervaricose segments (Fig. 4G).

\section{Distribution of MORI in brain}

MOR 1-ir was found in a number of regions throughout the brain and spinal cord. Two basic patterns of MOR1-ir were discerned. Neuronal perikarya and/or dendrites with prominent MOR1-ir were found in the cerebral cortex, striatum, nucleus accumbens, the septal nuclei, islands of Calleja, hippocampal regions, amygdaloid nuclei, several thalamic nuclei, habenular nuclei, interpeduncular nuclei, several raphe nuclei, the colliculi, parabrachial nuclei, locus coeruleus, nucleus ambiguus, nuclei of the sensory trigeminal complex, nucleus of the solitary tract, and the spinal cord dorsal horn. Instances of axons with prominent MOR1-ir were less common and were found in the pre- and parasubiculum, fasciculus retroflexus, accessory optic tract, and in primary afferent neurons terminating in the superficial dorsal horn of the spinal cord and sensory trigeminal complex. In general, the distribution of perikarya and dendrites correlated well with the distribution of neurons expressing mRNA encoding for MOR1, and was similar to the distribution of enkephalin. Details of the targeting of MOR 1-ir for several brain regions that have been important models for investigation of opioid function are presented below.

Striatum. Dense MOR1-ir was seen in patches in the striatum and in the subcallosal streak (Fig. $5 A, B$ ). There was also weak staining between the patches. Labeling was strongest in the patches located in the rostral-lateral portion of the striatum. A similar pattern of patches was revealed using in situ hybridization for MOR 1 (Fig. 5D). In addition, patches of dense MOR 1ir were observed in the nucleus accumbens as well as in the islands of Calleja. At higher magnification (Fig. 5C) fine, diffuse, punctate MOR1-ir was seen within the patches. This punctate staining surrounded small round profiles and may represent clusters of MOR 1 in the postsynaptic membrane of dendrites or clusters of receptors in the presynaptic membrane of nerve terminals. However, the former is likely, based upon double-staining experiments in which MORl-ir coincided more trequently with MAP2-ir, rather than tau- or synaptophysin-ir (data not shown). Although dendritcs appeared to be labcled, ncuronal perikarya containing MOR1-ir were not obvious within the striatum. Double staining using anti-MOR 1 and anti-enkephalin showed a fine, punctate network of enkephalin-ir varicosities throughout the striatum including areas within the MOR1-ir patches. At higher magnification (see Fig. 9A) enkephalin-ir was found in puncta that were separate from but closely apposed to MOR1-ir elements.

Hippocampal formation. At low magnification, dense MOR1ir was seen in the pre- and parasubiculum, angular bundle, dentate granule cell layer, and in the pyramidal cell layer of Ammon's horn (Fig. 6A). In the superficial laminae of the entorhinal cortex a few cells with processes projecting toward deeper laminae were observed to contain MOR 1 -ir. In the pre- and parasubiculum, anti-MORI labeled a fine, but very dense network of axons. At higher magnification staining in the hippocampus was observed in both perikarya and dendrites. Perikarya of granule cells near the interface of the granule cell layer and the hilus of the dentate gyrus were decorated with MOR 1-ir. The dendrites of these cell were also prominently labeled, but the labeling faded as they extended into the molecular layer (Fig. $6 B, D)$. The hilus contained a few MOR l-ir neurons and also a fine network of thin, nonvaricose processes. MOR1-ir coincided with the plasmalemma of perikarya and apical dendrites of cells within the pyramidal layer throughout the extent of Ammon's horn (regions C.A1-C.A3; Fig. 6A,C,E). Staining within the apical dendrites was prominent as they coursed through the stratum radiatum and expanded into a more diffuse pattern in the stratum lacunosum-moleculare, where they arborized. The basal dendrites of these cells also contained puncta of MOR1-ir and some 

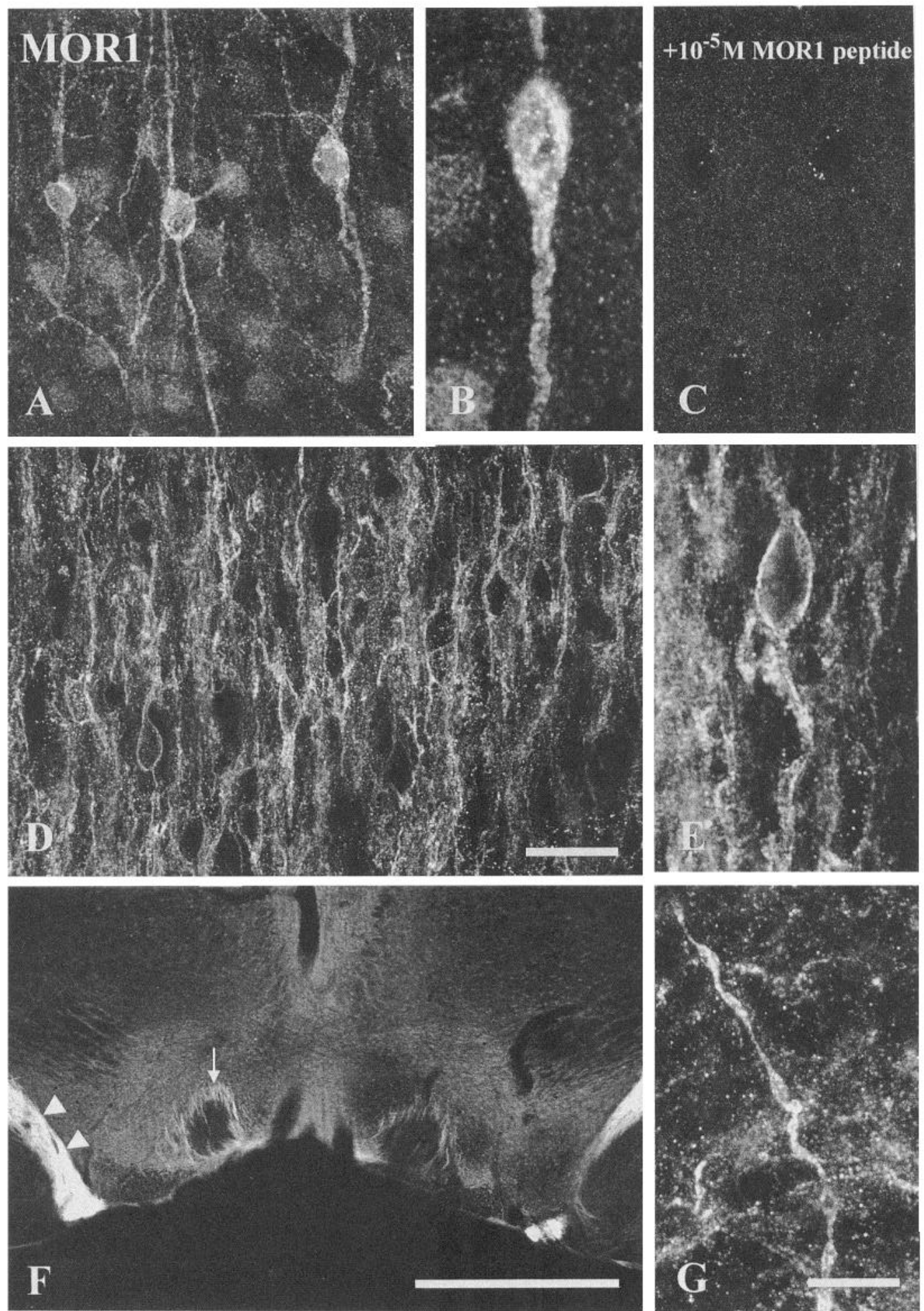

Figure 4. Cellular localization of MOR1-ir in the brain and spinal cord: sections of cortex $(A-C)$, spinal cord $(D, E)$, and midbrain $(F, G)$ stained with anti-MOR1 using immunofluorescence as visualized by confocal microscopy. Coronal sections from layers II-III of frontal cortex showed MOR 1-ir in cell bodies and processes $(A-C)$. Higher magnification of cortical neurons revealed MOR1-ir was associated with vesicle-like structures in the perikarya as well as in primary processes $(B)$. No staining was seen after preabsorption with cognate peptide $(C)$. Parasagittal section from the superficial dorsal horn of the spinal cord demonstrated MOR1-ir within the plasmalemma of the perikarya as well as the dendrites $(D, E)$. Note that MOR1-ir was concentrated in clusters along the membrane $(E)$. $F$, Coronal section from the midbrain demonstrated MOR1-ir in the axons of fasciculus retroflexus (arrow) and accessory medial optic tract (arrowheads). G, High magnification of varicose fiber from the brainstem showed an accumulation of MOR1-ir within vesicle-like structures in both varicosities and intervaricose segments. Scale bars: $A, C$, and $D, 25 \mu \mathrm{m} ; B, E$, and $G, 10 \mu \mathrm{m} ; F, 1000 \mu \mathrm{m}$. 


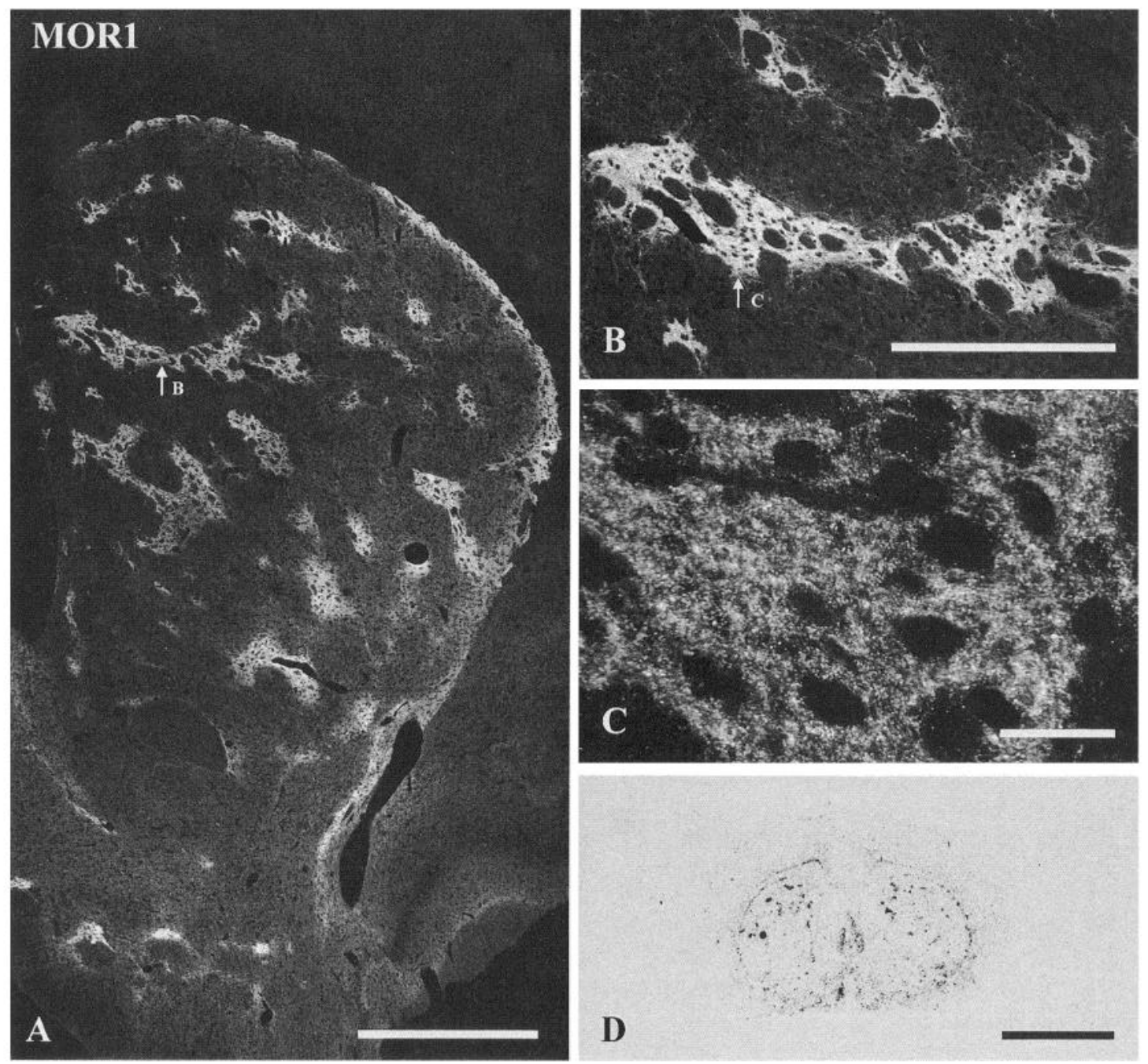

Figure 5. Distribution of MOR1 in the striatum. $A-C$, Confocal images of a coronal section stained with anti-MOR1. MOR1-ir was abundant within patches as well as in the subcallosal streak. Weak labeling was also present in the neuropil between the patches $(B)$. A fine, punctate labeling as well as a more diffuse labeling was seen in the patches at higher magnification $(C)$. Note clustering of MOR 1-ir around small-diameter (1-3 $\mu \mathrm{m}$ ) circular profiles, presumably dendrites, in the patches $(C)$. Using in situ hybridization, patches of cells expressing MOR 1 mRNA resembled the patches seen using anti-MOR1. Arrows in $A$ and $B$ refer to areas shown at higher magnification in $B$ and $C$, respectively. Scale bars: $A$, 1000 $\mu \mathrm{m} ; B, 500 \mu \mathrm{m} ; C, 25 \mu \mathrm{m} ; D, 5000 \mu \mathrm{m}$.

of these processes could be identified in their course toward the stratum oriens (Fig. 6C,E). Sparsely dispersed cells in stratum oriens also showed MOR1-ir. Enkephalin-ir fibers were seen throughout the hippocampal formation. However, particularly dense ENK immunoreactivity was seen in the pyramidal cell layer of CA2 and CA3, in the hilus of the dentate gyrus, and in the mossy fiber area. MOR1-ir profiles were seen in close proximity to ENK-ir fibers in CA2 and CA3, but no unequivocal instances of a perfect match were found (not shown).

Locus coeruleus. Prominent MOR1-ir was seen in the locus coeruleus (Fig. 7A). This correlated well with MOR1 mRNA expression as determined by in situ hybridization (Fig. 7C). As in the striatum, a combination of diffuse and punctate staining was seen at higher magnification (Fig. $7 B$ ). MOR1-ir was seen outlined the contours of some perikarya and small rounded profiles within the neuropil. MOR 1-ir was not apparent within the cytoplasm of neurons in locus coeruleus. Enkephalin-ir within locus coeruleus was sparse but mingled among MOR1-ir perikarya and dendrites (see Fig. 9B). Double-labeling experiments using anti-MOR1 and antibodies to dopamine $\beta$-hydroxylase or tyrosine hydroxylase were carried out on sections sampled from throughout the brain and spinal cord known to receive input from axons of locus coeruleus neurons. Few cases of coexistence were observed, suggesting that targeting of MOR 1 in locus coeruleus neurons is restricted to the somatodendritic domain, and not axons.

Spinal cord dorsal horn. The superficial dorsal horn of the spinal cord contained a dense network of MOR 1-ir at all spinal levels (Fig. $8 A$ ). This network consisted not only of varicosities (Fig. $8 F$ ) but also of the plasmalemma of neuronal perikarya and dendrites (Figs. $4 D, E ; 8 F ; 9 C$ ). In parasagittal sections, perikarya exhibiting MOR1-ir could be seen to extend their processes in a rostrocaudal orientation (compare Figs. $4 D, 9 C$ with $8 F$ ). The staining of MOR1-ir varicosities in the superficial dorsal horn decreased after dorsal rhizotomy (Fig. $8 B$ ) whereas the staining for MOR1-ir in perikarya in this region was not altered, supporting the idea that many of the axons with MOR1-ir in the dorsal horn originate from dorsal root ganglion cells. This is 

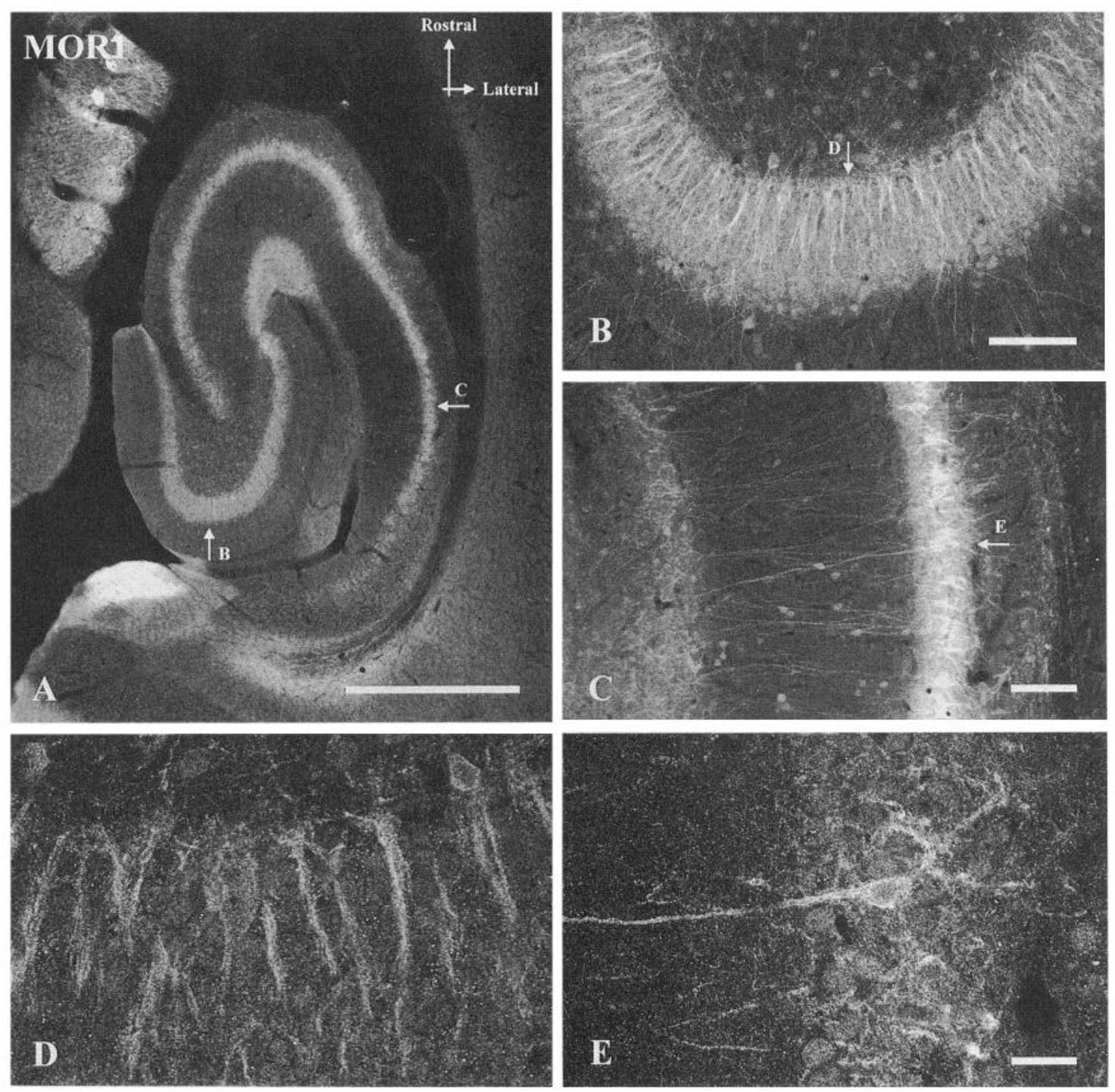

Figure 6. Localization of MOR1-ir in the hippocampal formation: horizontal section stained with anti-MOR1. A, Low-power confocal image illustrating the widespread distribution of MOR1-ir in the hippocampal formation. Note the dense accumulation of MOR1-ir in the pre- and parasubiculum, in the dentate granule cell layer, and in the pyramidal cell layer of Ammons horn. In the dentate gyrus, MOR1-ir was seen within the somatic and dendritic plasmalemma of granule cells $(B, D)$. Note weak staining of cells and processes in the hilar region $(B)$. A subset of pyramidal cells in the CA1 region of Ammons horn exhibited MOR1-ir in puncta within the cytoplasm of perikarya and processes as well as in the plasmalemma of the soma and the basal and apical processes $(C, E)$. Arrows labeled $B-E$ refer to the areas shown at higher magnification in panels $B-E$, respectively. Orientation given in $A$ applied to all plates. Scale bars: $A, 1000 \mu \mathrm{m} ; B$ and $C, 100 \mu \mathrm{m} ; D$ and $E, 25 \mu \mathrm{m}$.

further supported by evidence showing that a subset of neurons in dorsal root ganglia stained with anti-MOR1 (Fig. $8 \mathrm{C}$ ). In these cells a punctate staining pattern was seen within the cytoplasm and axoplasm, as well as in the somatic plasmalemma (Fig. 8D); the punctate staining could possibly represent vesicles transporting the receptor. Neurons in dorsal root ganglia containing MOR1-ir were small to medium in size and did not stain for RT97, a neurofilament protein seen in large myelinated primary afferents (Fig. $8 E, E^{\prime}$ ). This suggests that MOR1 is localized to neurons that give rise to unmyelinated primary afferents. In addition to double-labeling experiments with anti-MOR 1 and enkephalin, double-labeling experiments were performed with an antiserum to another enkephalin-preferring opioid receptor, namely the $\delta$-opioid receptor (DOR1; Dado et al., 1993; Arvidsson et al., 1995). In contrast to labeling for MOR1, no evidence for labeling of postsynaptic structures could be seen for enkephalin or DOR1. In the superficial dorsal horn, varicosities coexpressing MOR 1 and DOR 1 could be seen (Fig. $8 F, F^{\prime}$ ). The same pattern of coexistence was observed in neurons in DRG. No such coexistence was seen in the dorsal horn after dorsal rhizotomy. The distribution of MOR 1 and enkephalin in the dorsal horn overlapped in superficial dorsal horn but not in deeper laminae (Fig. 9C). Occasionally, several enkephalin-immunopositive varicosities were seen in the vicinity of MOR1-positive clusters in the plasmalemma (arrow in Fig. 9C).

\section{Discussion}

The pattern of receptors on the plasmalemma of neurons determines the nature of neurotransmission. Synaptic neurotransmission, as at the neuromuscular junction, requires targeting of receptors to the postsynaptic membrane immediately subjacent to the site of transmitter release. Little is known concerning the 
Figure 7. Localization of MOR1 in locus coeruleus: immunofluorescent confocal images of locus coeruleus stained with anti-MOR1 $(A, B)$, and autoradiograph after in situ hybridization for MORI mRNA $(C)$. Dense MOR1ir was seen in the somatic plasmalemma (arrows in B) of locus coeruleus neurons as well as in the neuropil surrounding cross-sectioned profiles ( $A$, $B) . B$ is a higher-magnification image from the same field as $A$. Neurons in locus coeruleus were also strongly labeled for MORI mRNA $(C)$. Scale bars: $A, 100 \mu \mathrm{m} ; B, 25 \mu \mathrm{m} ; C, 250$ $\mu \mathrm{m}$.
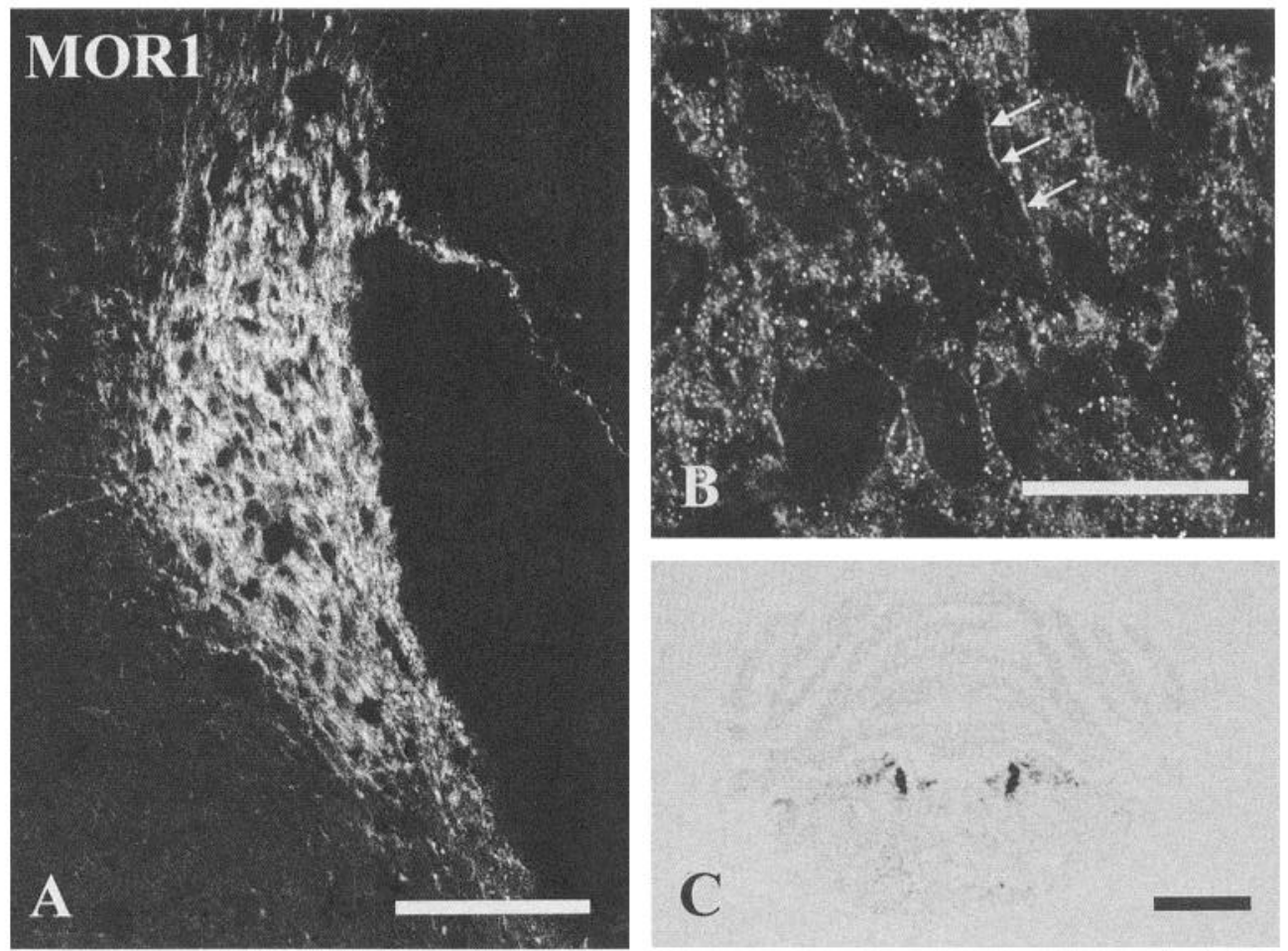

trafficking of neuropeptide receptors. To date DOR 1 has been shown to be targeted primarily to axons, where it most likely functions presynaptically (Dado et al., 1993; Arvidsson et al., 1995), whereas a substance $P$ receptor has been shown to be targeted to the plasma membrane of the somatodendritic domain, where it most likely functions postsynaptically (Liu et al., 1994; Nakaya et al., 1994). Thus, it was of interest to determine if neurons were capable of targeting MORl to axons or somatodendritic domains, or both.

\section{Specificity of MORI antisera}

The antisera used in these studies were raised against a synthetic peptide corresponding to the last 15 amino acids of the C-terminus of MOR 1 (Chen et al., 1993; Fukuda et al., 1993; Thompson et al., 1993). Both tissue sections and transfected cell lines could be immunostained with these antisera and the staining was abolished when anti-MORI sera were preincubated with the peptide against which they were raised. Based on epitope mapping studies, all antisera appeared to have a similar epitope, which was determined to be within the last 5-8 amino acids. Further characterization demonstrated that the antisera detected proteins with an $M_{r}$ of $67-72 \mathrm{kDa}$ on Western blots of membrane proteins from brain and transfected cells. It should be noted that the MOR 1 cDNA clone predicts a protein with a mass of 45 $\mathrm{kDa}$. However, the sequence has five potential sites for $\mathrm{N}$-linked glycosylation, two consensus sites for palmitoylation and three possible sites for phosphorylation (Thompson et al., 1993). Thus, the discrepancy in the predicted mass of MORI and the apparent mass of MOR1-ir as determined by Western blots is likely a result of posttranslational modifications.

Other points further support the specificity of the antisera. The antisera (1) immunoisolated a membrane protein capable of binding $\beta$-endorphin and having a molecular weight of 63-67 $\mathrm{kDa},(2)$ stained COS-7 and Neuro $2 \mathrm{a}$ cell lines transfected with MORI, (3) stained only those COS-7 and Neuro2a cells that were also stained for TAG (in preparations transfected with MORTAG), (4) were selective for the $\mu$-opioid receptor, since cell lines transfected with $\delta$ - or $\kappa$-opioid receptors were not stained by the antisera, and (5) stained brain and spinal cord in a pattern that mirrored that seen in autoradiographic studies of opioid binding as well as a pattern similar to that seen by in situ hybridization for MOR1. Thus, several lines of evidence support the conclusion that the antisera used in the present study most likely recognize a bona fide $\mu$-opioid receptor.

Our findings with these antisera differ substantially from those in a recent report (Hiller et al., 1994) in which antisera were raised against a peptide from a $\mu$-opioid binding protein isolated from bovine brain. Our findings also differ from an earlier report (Hassan et al., 1989) that used anti-idiotypic antibodies that recognize both $\mu$ - and $\delta$-opioid receptors. In each of these studies it is possible that the proteins they have localized may be $\mu$-opioid receptors; however, they are clearly not MORI.

\section{Intracellular targeting of MORI and comparison to DORI}

Study of the cellular distribution of opioid receptors in neurons is important as a first step in determining the mechanisms by which they traffic. MOR1 is found predominantly in the somatodendritic domain. However, the somatodendritic distribution of MORI was different among different groups of cells: in the superficial dorsal horn of the spinal cord the receptor was visible only on the plasmalemma, whereas in the cerebral cortex, hippocampus, and dorsal root ganglia it was visible in the cytoplasm and occasionally on the plasmalemma. The reason for these differences is unclear, but it might be that differences exist in receptor turnover, trafficking, or rates of internalization. Also, the immunoreactivity in some neurons could be seen in patches on the somatic and dendritic plasmalemma. It would be of interest to determine whether the receptor at these sites is concentrated where presynaptic terminals containing endogenous opioids make contact (see below). 

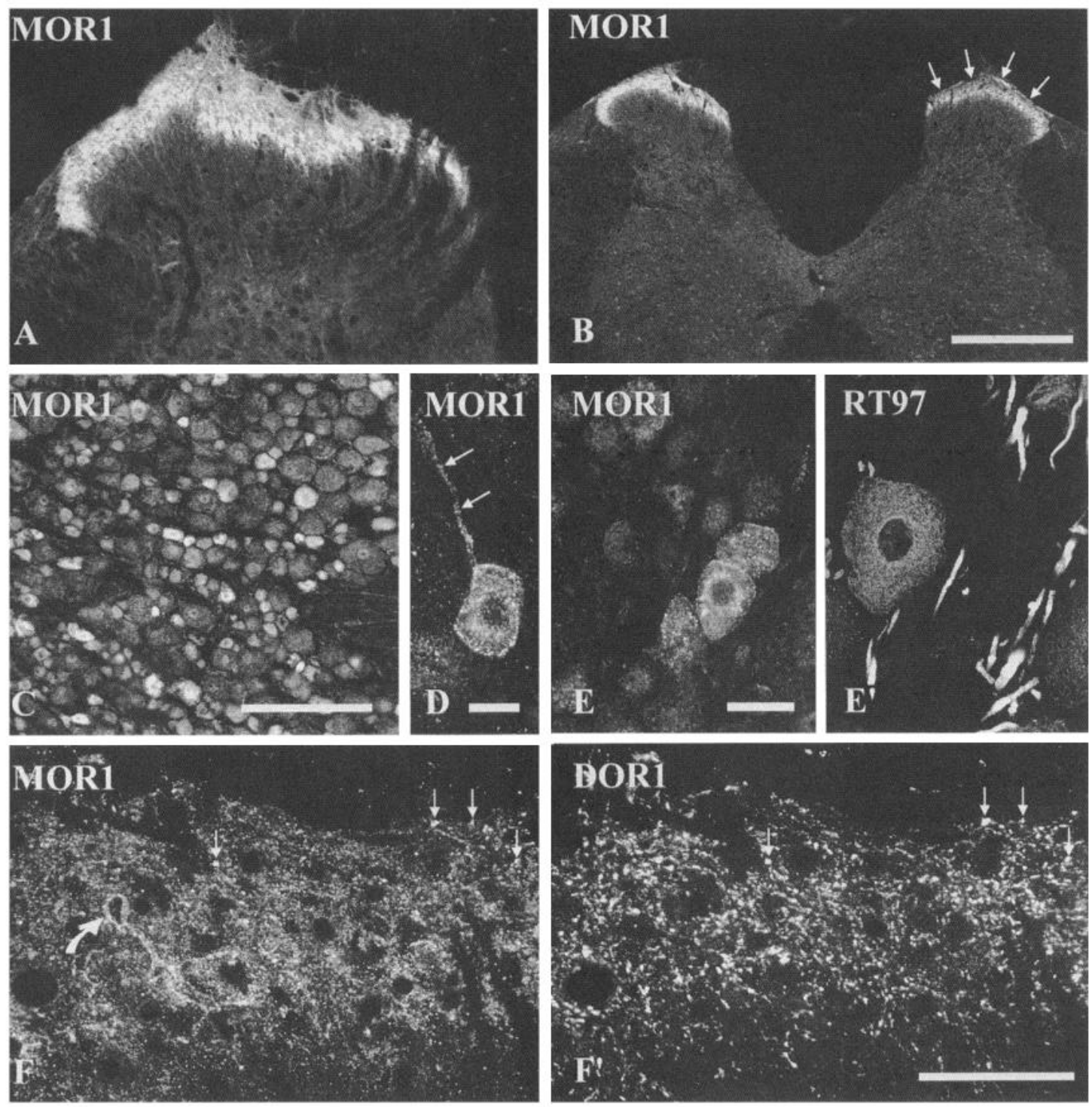

Figure 8. Localization of MOR1-ir in the spinal cord and dorsal root ganglion cells: immunofluorescent confocal images of the dorsal horn and dorsal root ganglion stained with anti-MOR1 $(A-F)$, RT97 $\left(E^{\prime}\right)$, or anti-DOR1 $\left(F^{\prime}\right)$. Dense MOR1-ir was seen in the superficial dorsal horn $(A)$. $B$, Seven days after a unilateral dorsal rhizotomy, a reduction of the labeling was apparent on the ipsilateral side, especially in lamina $\mathrm{I}$ and outer lamina II (arrows), but labeling remained in inner lamina II. C, A subset of small- to medium-sized dorsal root ganglion cells demonstrated MOR1ir. At higher magnification, MOR I-ir was observed in vesicle-like structures, and these were sometimes found in axons $(D)$. In addition, MOR 1-ir was observed in the somatic plasmalemma of some neurons. The majority of the MOR1-positive cells in the dorsal root ganglion did not stain for RT97 $\left(E, E^{\prime}\right)$. MOR1-ir was found in the plasmalemma of small cells and their processes $(F$, curved arrow) as well as in axonal varicosities $(F)$. MOR I-ir was present in a subset of DOR I-positive axonal varicosities in the dorsal horn (arrows in $F, F^{\prime}$ ). Scale bars: $A$ and $C, 250 \mu$ m; $B, 500$ $\mu \mathrm{m} ; D, 10 \mu \mathrm{m} ; E$ and $E^{\prime}, 20 \mu \mathrm{m} ; F$ and $F^{\prime}, 50 \mu \mathrm{m}$.

In earlier studies axonal transport of opioid receptors was predicted, for instance, in the projections of dorsal root ganglion cells to the superficial dorsal horn (LaMotte et al., 1976; Zajac et al., 1989; Besse et al., 1990; Laduron and Castel, 1990) and in the accessory medial optic tract (Giolli et al., 1990). In the present study, MOR I staining was seen within varicose fibers in the dorsal horn. Some of these fibers stained with markers for axons, anti-tau and anti-synaptophysin, as well. In addition, MOR1 staining in the superficial dorsal horn decreased after dorsal rhizotomy. Thus, in some cases MORI appears likely to occur in axons and axonal terminals. No unambiguous cases of staining of axonal plasmalemma were observed. Rather, a fine punctate labeling, possibly representing vesicles, was seen. This suggests that MOR1 is transported to axonal terminals in a ve- sicular compartment rather than within the plasmalemma. The latter also appears to be the case for DORI (Arvidsson et al., 1995), and it is possible that neurotransmitter receptors on presynaptic terminals are transported and inserted by a regulated rather than a constitutive pathway. The mechanism by which MOR 1 and DOR1 are inserted into the plasmalemma of terminals might be controlled in a manner similar to that of neurotransmitter release.

Thus, neuronal targeting of MOR1 contrasts with that previously reported for DOR1 (Pasquini et al., 1992; Dado et al., 1993; Arvidsson et al., 1995); DOR1 appears likely to act exclusively as a presynaptic receptor whereas MOR1 seems poised to act as both a pre- and postsynaptic receptor. Other receptors appear to be similarly restricted in their intracellular targets; sub- 

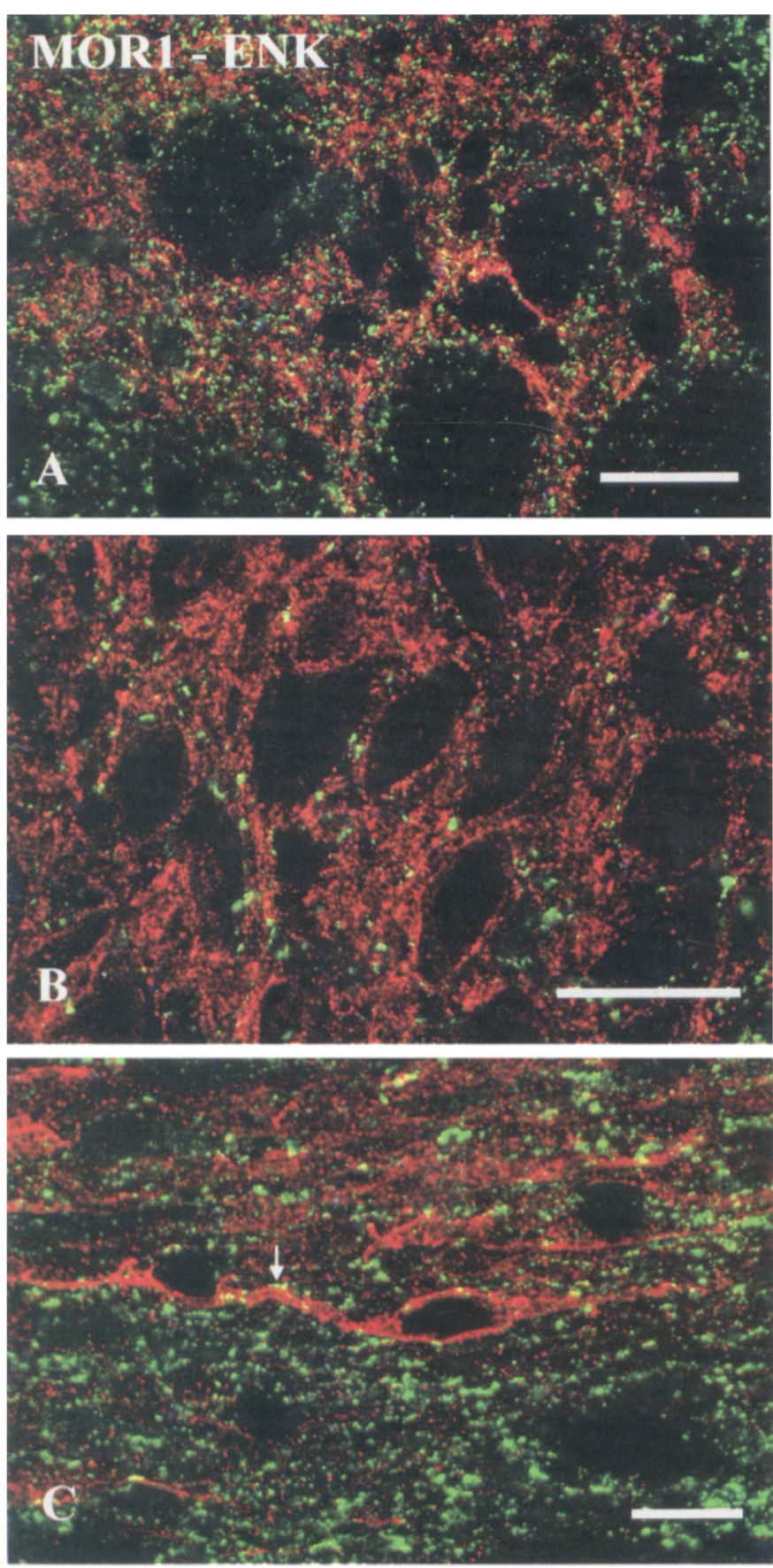

Figure 9. Match and mismatch of MOR1-ir with enkephalin-ir: highmagnification confocal images of striatum $(A)$, locus coeruleus $(B)$, and spinal cord dorsal horn $(C)$ stained with anti-MOR1 (red) and antienkephalin (green). A, Coronal section. The distribution of MOR1-ir frequently matched that of enkephalin-ir in striatal patches. Enkephalinlabeled varicosities were also present outside patches. $B$, Coronal section of locus coeruleus. Varicosities with enkephalin-ir were found near MOR1-labeled structures, but the amount of enkephalin labeling was less. $C$, Parasagittal section of the superficial dorsal horn. Enkephalinpositive varicosities were occasionally closely apposed to clusters of MOR1-ir on the plasmalemma of neurons (arrow). This was less common ventral to the substantia gelatinosa (lower portion of $C$ ). All three images are projections of six optical sections $0.4 \mu \mathrm{m}$ apart. Scale bars, $25 \mu \mathrm{m}$. stance P and NPY Y1 receptors both appear to be incorporated exclusively into the somatodendritic domain (Liu et al., 1994; Nakaya et al., 1994; Zhang et al., 1994). The mechanisms by which neurons control the intracellular trafficking of receptors to axons versus dendrites or both are still not known.

\section{Distribution of MORI in the rat brain and spinal cord}

The overall distribution of MOR1 is in agreement with earlier studies on $\mu$-opioid binding sites in the brain and spinal cord (Mansour et al., 1987; Tempel and Zukin, 1987; Mansour and Watson, 1993). Previous autoradiographic studies could not unequivocally identify the cellular location of these binding sites. However, immunocytochemical studies using antisera that recognize the receptor provide a more exact localization. Comparison of our immunocytochemical data with in situ hybridization experiments showed that the regional pattern of MOR1-ir correlates well with the distribution of mRNA coding for MOR1, as seen in the present article as well as in previous studies (Thompson et al., 1993; Delfs et al., 1994; Mansour et al., 1994). Pharmacological studies have proposed on the basis of different binding characteristics of ligands the presence of two $\mu$-opioid receptor subtypes referred to as $\mu 1$ and $\mu 2$ (Pasternak, 1993), but it is presently unclear which of these corresponds to MOR1.

The highest densities of MOR 1 in the brain were found in the cortex, caudate-putamen, habenula and interpeduncular nuclei (as well as in the fiber bundles connecting these two areas), hippocampus, hypothalamic nuclei, raphe medianus, inferior colliculus, parabrachial nuclei, locus coeruleus, ambiguus nucleus, sensory trigeminal complex, nucleus of the solitary tract, and spinal cord dorsal horn. This distribution suggests that this receptor protein may be important in mediating functions such as motor rigidity, autonomic reflexes, endocrine functions, behavioral and mood effects as well as analgesia.

In the hippocampal formation MOR l-ir was prominent in the granule cell layer in the dentate gyrus as well as in the pyramidal cell layer of Ammon's horn. In both cases the staining was prominent in the plasmalemma of neuronal perikarya and dendrites. Electrophysiological studies on hippocampal slices have shown that activation of $\mu$-opioid receptor decreases GABA release from interneurons leading to an indirect excitation of pyramidal neurons (i.e., disinhibition; Cohen et al., 1992; Thompson, 1994). Disinhibitory mechanisms have also been reported for granule cells in the dentate gyrus (Xie et al., 1992). Thus, our findings argue that at least some of the MOR1-positive neurons represent GABAergic inhibitory interneurons. It should also be noted that the distribution of neurons containing MOR1-ir resembles the distribution GABAergic neurons as determined by immunostaining for glutamic acid decarboxylase (Mugnaini and Oertel, 1985; see also Buhl et al., 1994).

Release of noradrenaline from rat brain slices is inhibited by activation of $\mu$-opioid receptors (for references, see Mulder and Schoffelmeer, 1993). Also, $\mu$-opioid receptor agonists inhibit noradrenaline release from synaptosomes (Mulder et al., 1987), suggesting that $\mu$-opioid receptors occur on noradrenergic terminals. In the present study MOR1-ir was seen in the somatic plasmalemma of locus coeruleus neurons, suggesting that the MOR1 receptor may be responsible for the effects of opiates on these cells (Harris and Williams, 1991). However, in either the brain or spinal cord, very few D $\beta H$ - or TH-positive axonal terminals stained for MOR 1, suggesting that MOR 1 is not predominantly transported to noradrenergic terminals. The discrepancy between our anatomical findings and the previous pharmacolog- 
ical studies may be due to, as recently demonstrated, the existence of alternate splicing of $\mu$-opioid receptor mRNA producing different isoforms of the receptor (Zimprich et al., 1994). This isoform, termed MORIb, varies in length and the composition of the carboxy-terminus from MOR 1 . Since our antisera are directed against the last 5-8 amino acids at the carboxyterminus, it is unlikely that anti-MOR I would recognize the MOR Ib isoform. Thus, a plausible explanation could be that locus coeruleus neurons target MORl to their somatodendritic domain whereas MORlb is targeted to their axons. A test of this hypothesis awaits the availability of antisera selective for MOR Ib.

In the superficial dorsal horn MOR 1-ir was present on membranes of neurons as well as on axon terminals. Some of the MOR 1-labeled terminals probably derive from dorsal root ganglion cells since a dorsal rhizotomy decreased the staining of MORI in laminae I and outer II. Thus, MOR 1 appears to be localized both pre- and postsynaptically in the dorsal horn and therefore to be poised to modulate both the release of transmitters from primary afferent neurons and the responses of dorsal horn neurons. This conclusion is in agreement with numerous studies using electrophysiological, pharmacological, and anatomical techniques (Fleetwood-Walker et al., 1988; Besse et al., 1990; Dong et al., 1991; Herrero and Headley, 1991; Thompson et al., 1993; Glaum et al., 1994; Grudt and Williams, 1994).

The population of dorsal root ganglion neurons that stained for MOR I was predominantly negative for RT97, a marker for large, myelinated primary afferents (Lawson and Waddell, 1991). This finding suggests that MORl is mainly localized to small-diameter primary afferent neurons, some of which mediate nociception.

Interestingly, a subset of MOR I-positive axon terminals in the superficial dorsal horn stained also for DOR 1. A $\delta$ - $\mu$-receptor complex has been suggested from the diverse and complex pharmacology of the opioids (for references, see Rothman et al., 1993). Inhibition of substance $P$ release from cat hypothalamic slices has been found to involve both a $\mu$ - and a $\delta$-opioid receptor (Micevych et al., 1984). It remains to be determined whether similar regulation occurs in the dorsal horn.

As described above, $\mu$-opioid receptors may inhibit both primary afferent terminals as well as local neurons in the dorsal horn to produce antinociception. In addition, areas implicated in supraspinal analgesia also stained for MOR 1, including nucleus raphe magnus in the rostral ventromedial medulla and caudal pons, locus coeruleus, and the periaqueductal gray. This suggests that the $\mu$-opioid receptor also may be involved in descending mechanisms of antinociception that are mediated by opioids (see Basbaum and Fields, 1984).

\section{Spatial distribution of MORI in relation to enkephalin}

Several earlier studies have examined the distribution of receptors in relation to putative endogenous ligands in the brain and found that matches as well as mismatches exist (for references, see Herkenham, 1987). The opioid system is complex, in that there are three pharmacological types of receptors $(\mu, \delta$, and $\kappa)$ as well as subtypes of these receptors, each of which has significant affinity for more than one of several possible endogenous ligands. The endogenous ligand(s) for $\mu$-opioid receptors has not been established, but leading candidates have been $\beta$-endorphin, enkephalins (Corbett et al., 1993; Raynor et al., 1994), and endogenously synthesized morphine (Goldstein et al., 1985). From earlier studies the overall correlations between opioid pep- tides (as demonstrated by immunohistochemistry) and opioid receptors (as demonstrated by binding studies using autoradiography) match poorly in the majority of systems (for refs see Herkenham, 1987). In the present report a direct comparison between MORI and the enkephalins has been studied. (Immunofluorescent double-labeling experiments comparing MOR I staining with that for other putative endogenous ligands such as $\beta$-endorphin have not been possible since antisera raised in species other than rabbits have not been available.) A match (or apposition) between enkephalin-ir varicosities and MORI labcling was found occasionally in areas such as the dorsal horn and the striatum (see Fig. 9A,C), but more commonly we observed a quantitative or a distributional mismatch. Quantitative mismatches were exemplified by regions such as the locus coeruleus in which MOR l-ir was prominent and enkephalin-ir was sparse (see Fig. 9B). Distributional mismatches were exemplified by the deeper layers of the dorsal horn of the spinal cord in which enkephalin-ir varicosities were found in the absence of elements containing MOR 1 -ir (see Fig. $9 C$ ). These findings may indicate that opioids are involved in a diffuse mode of neurotransmission on surrounding elements (e.g., volume transmission; for references, see Fuxe and Agnati, 1991). That such organization occurs was recently shown in an electron microscopic study on the spatial relationship between substance $P$ and a substance $P$ receptor (Liu et al., 1994). It was found that much of the cell surface of substance $P$ receptor-positive ncurons was immunostained for the receptor $(\sim 70 \%)$. However, a small fraction of the immunostained plasmalemma $(<15 \%)$ was apposed by presynaptic terminals, only a few of which were determined to contain substance $P$. The present studies suggest that a similar pattern may exist between MORl and enkephalin although confirmation must await electron microscopic studies.

\section{References}

Arvidsson U, Dado RJ, Riedl M, Lee J-H, Law P-Y, Loh HH, Elde R, Wessendorf MW (1995) Delta ( $\delta$ )-opioid receptor immunoreactivity: distribution in brain stem and spinal cord and relationship to biogenic amines and enkephalin. J Neurosci 15:1215-1235.

Basbaum AI, Fields HL (1984) Endogenous pain control systems: brainstem spinal pathway and endorphin circuitry. Annu Rev Neurosci 7:309-338.

Bergsbaken CL, Sommers SL, Law PY (1993) Effect of forskolin and isobutylmethylxanthine on delta-opioid receptor activity in neuroblastoma $X$ glioma NG108-15 cells. J Pharmacol Exp Ther 264:14741483.

Besse D, Lombard MC, Zajac JM, Roques BP, Besson JM (1990) Preand postsynaptic distribution of mu, delta and kappa opioid receptors in the superficial layers of the cervical dorsal horn of the rat spinal cord. Brain Res 521:15-22.

Brelje TC, Wessendorf MW, Sorenson RL (1993) Multicolor laser scanning confocal immunofluorescence microscopy: practical application and limitations. Methods Ccll Biol 38:97-181.

Buhl EH, Halasy K, Somogyi P (1994) Diverse sources of hippocampal unitary inhibitory postsynaptic potentials and the number of synaptic release sites. Nature 368:823-828.

Chen CA, Okayama H (1988) Calcium phosphate-mediated gene transfer: a highly efficient transfection system for stably transforming cells with plasmid DNA. Biotechniques 6:632-638.

Chen Y, Mestek A, Liu J, Hurley JA, Yu L (1993) Molecular cloning and functional expression of a mu-opioid receptor from rat brain. Mol Pharmacol 44:8-12.

Cohen GA, Doze VA, Madison DV (1992) Opioid inhibition of GABA release from presynaptic terminals of rat hippocampal interneurons. Neuron 9:325-335.

Coons AH (1958) Fluorescent antibody methods. In: General cytochemical methods (Daniclii JF, ed), pp 390-422. New York: $\Lambda$ cadem ic.

Corbett AD, Paterson SJ, Kosterlitz HW (1993) Selectivity of ligands 
for opioid receptors. In: Handbook of experimental pharmacology, Opioids I (Herz A, ed), pp 645-679. Berlin: Springer.

Dado RJ, Law PY, Loh HH, Elde R (1993) Immunofluorescent identification of a delta ( $\delta$ )-opioid receptor on primary afferent nerve terminals. Neuroreport 5:341-344.

Delfs JM, Kong H, Mestek A, Chen Y, Yu L, Reisine T, Chesselet M-F (1994) Expression of mu opioid receptor mRNA in rat brain: an in situ hybridization study at the single cell level. J Comp Neurol 345: $46-68$.

Dong XW, Parsons CG, Headley PM (1991) Effects of intravenous mu and kappa opioid receptor agonists on sensory responses of convergent neurones in the dorsal horn of spinalized rats. Br J Pharmacol 103:1230-1236.

Evans CJ, Keith DJ Jr, Morrison H, Magendzo K, Edwards RH (1992) Cloning of a delta opioid receptor by functional expression. Science 258:1952-1955.

Fleetwood-Walker SM, Hope PJ, Mitchell R, el-Yassir N, Molony V (1988) The influence of opioid receptor subtypes on the processing of nociceptive inputs in the spinal dorsal horn of the cat. Brain Res $451: 213-226$.

Fukuda K, Kato S, Mori K, Nishi M, Takeshima H (1993) Primary structures and expression from CDNAs of rat opioid receptor deltaand mu-subtypes. FEBS Lett 327:311-314.

Fuxe K, Agnati LF. eds (1991) Advances in neuroscience, Volume transmission in the brain: novel mechanisms for neuronal transmission. New York: Raven.

Giolli RA, Blanks RH, Torigoe Y, Clarke RJ, Fallon JH, Leslie FM (1990) Opioid receptors in the accessory optic system of the rat: effects of monocular enucleation. Vis Neurosci 5:49\%-506.

Glaum SR, Miller RJ, Hammond DL (1994) Inhibitory actions of $\delta 1$-, $\delta 2-$, and $\mu$-opioid receptor agonists on excitatory transmission in lamina II neurons of adult rat spinal cord. J Neurosci 14:4965-4971.

Goldstein A, Barrett R, James I, Lowney L, Weitz C, Knipmeyer L, Rapoport H (1985) Morphine and other opiates from beef brain and adrenal. Proc Natl Acad Sci USA 82:5203-5207.

Grudt TJ, Williams JT (1994) mu-Opioid agonists inhibit spinal trigeminal substantia gelatinosa neurons in guinea pig and rat. $\mathbf{J}$ Neurosci $14: 1646-1654$.

Harris GC, Williams JT (1991) Transient homologous mu-opioid receptor desensitization in rat locus coeruleus neurons. J Neurosci 11: $2574-2581$

Hassan AH, Almeida OF, Gramsch C, Herz A (1989) Immunocytochemical demonstration of opioid receptors in selected rat brain areas and neuroblastoma $\times$ glioma hybrid (NG108-15) cells using a monoclonal anti-idjotypic antibody. Neuroscience 32:269-278.

Herkenham M (1987) Mismatches between neurotransmitter and receptor localizations in brain: observations and implications. Neuroscience 23:1-38.

Herrero JF, Headley PM (1991) The effects of sham and full spinalization on the systemic potency of mu- and kappa-opioids on spinal nociceptive reflexes in rats. Br J Pharmacol 104:166-170.

Herz. A. ed (1993) Handbook of experimental pharmacology, Opioids II. Berlin: Springer.

Hiller JM, Zhang Y, Bing G, Gioannini TL, Stone EA, Simon EJ (1994) Immunohistochemical localization of mu-opioid receptors in rat brain using antibodies generated against a peptide sequence present in a purified mu-opioid binding protein. Neuroscience, in press.

Howard AD, de LBS, Gioannini TL, Hiller JM, Simon EJ (1985) Covalent labeling of opioid receptors with radioiodinated human betaendorphin. Identification of binding site subunit. J Biol Chem 260: 10833-10839

Keefer JR, Limbird LE (1993) The alpha 2A-adrenergic receptor is targeted directly to the basolateral membrane domain of Madin-Darby canine kidney cells independent of coupling to pertussis toxinsensitive GTP-binding proteins. J Biol Chem 268:11340-11347.

Kieffer BL, Befort K, Gaveriaux RC, Hirth CG (1992) The delta-opioid receptor: isolation of a cDNA by expression cloning and pharmacological characterization. Proc Natl Acad Sci USA 89:12048-12052.

Ko J, Lee N, Loh H (1992) Characterization of beta- ${ }^{125}$ I-endorphin cross-linked proteins in NG108- 15 cell membranes. A 25-kilodalton protein with properties of delta-opioid-binding site. J Biol Chem 267: 12722-12727.

Laduron PM, Castel MN (1990) Axonal transport of receptors. A major criterion for presynaptic localization. Ann NY Acad Sci 604:462469.
LaMotte CC, Pert CB, Snyder SH (1976) Opiate receptor binding in primate spinal cord: distribution and changes after dorsal root section. Brain Res 112:407-412.

Lawson SN, Waddell PJ (1991) Soma neurofilament immunoreactivity is related to cell size and fibre conduction velocity in rat primary sensory neurons. J Physiol (Lond) 435:41-63.

Liu H, Brown JL. Jasmin L, Maggio JE, Vigna SR, Mantyh PW, Basbaum AI (1994) Synaptic relationship between substance $P$ and the substance $P$ receptor: light and electron microscopic characterization of the mismatch between neuropeptides and their receptors. Proc Natl Acad Sci USA 91:1009-1013.

Lutz RA, Pfister HP (1992) Opioid receptors and their pharmacological profiles. J Receptor Res 12:267-286.

Mansour A, Watson SJ (1993) Anatomical distribution of opioid receptors in mammalians: an overview. In: Handbook of experimental pharmacology, Opioids I (Her7. A, ed), pp 79-102. Berlin: Springer.

Mansour A, Khachaturian H, Lewis ME, Akil H, Watson SJ (1987) Autoradiographic differentiation of $\mathrm{mu}$, delta, and kappa opioid receptors in the rat forebrain and midbrain. J Neurosci 7:2445-2464.

Mansour A. Fox CA, Thompson RC, Akil H, Watson SJ (1994) muOpioid receptor mRNA expression in the rat CNS: comparison to mu- receptor binding. Brain Res 643:245-265.

Micevych PE, Yaksh TL, Go VL (1984) Studies on the opiate receptormediated inhibition of $\mathrm{K}^{+}$-stimulated cholecystokinin and substance $P$ release from cat hypothalamus in vitro. Brain Res 290:87-94.

Mugnaini E, Oertel WH (1985) An atlas of the distribution of GA$B$ Aergic neurons and terminals in the rat $\mathrm{CNS}$ as revealed by GAD immunohistochemistry. In: Handbook of chemical neuroanatomy. GABA and neuropeptides in the CNS (Björklund A, Hökfelt ' 1 ' eds), pp 436-608. Amsterdam: Elsevier.

Mulder AH, Schoffelmeer ANM (1993) Multiple opioid receptors and presynaptic modulation of neurotransmitter release in the brain. In Handbook of experimental pharmacology, Opioids I (Herz A, ed), pp 125-144. Berlin: Springer

Mulder AH, Hogenboom F, Wardeh G, Schoffelmeer AN (1987) Morphine and enkephalins potently inhibit $\left[{ }^{3} \mathrm{H}\right]$ noradrenaline release from rat brain cortex synaptosomes: further evidence for a presynaptic localization of mu-opioid receptors. J Neurochem 48:1043-1047.

Nakaya Y, Kaneko T, Shigemoto R, Nakanishi S, Mizuno N (1994) Immunohistochemical localization of substance $\mathrm{P}$ receptor in the central nervous system of the adult rat. J Comp Neurol 347:249-274.

Pasquini F, Bochet P. Garbay-Jaureguiberry C, Roques BP, Rossier J, Beaudet A (1992) Electron microscopic localization of photoaffinitylabelled delta opioid receptors in the neostriatum of the rat. J Comp Neurol 326:229-244.

Pasternak GW (1993) Pharmacological mechanisms of opioid analgesics. Clin Neuropharmacol 16:1-18.

Raynor K, Kong H, Chen Y, Yasuda K, Yu L, Bell GI, Reisine T (1991) Pharmacological characterization of the cloned kappa-, delta-, and mu- opioid receptors. Mol Pharmacol 45:330-334.

Roerig SC, Loh HH, Law PY (1992) Identification of three separate guanine nucleotide-binding proteins that interact with the delta-opioid receptor in NG108-15 neuroblastoma $\times$ glioma hybrid cells. Mol Pharmacol 41:822-831.

Rothman RB, Holaday JW, Porreca F (1993) Allosteric coupling among opioid receptors: evidence for an opioid receptor complex. In: Handbook of experimental pharmacology, Opioids I (Herz A, ed), pp 217-237. Berlin: Springer.

Simmons DM, Arriza JL, Swanson LW (1989) A complete protocol for in situ hybridization of messenger RNAs in brain and other tissues with radiolabeled single-stranded RNA probes. J Histotechnol 12: $169-181$

Simon EJ (1991) Opioid receptors and endogenous opioid peptides Med Res Rev 11:357-374.

Simon EJ, Gioannini TL (1993) Opioid receptor multiplicity: isolation, purification, and chemical characteriration of binding sites. In: Handbook of experimental pharmacology, Opioids I (Herz A, ed), pp 3 26. Berlin: Springer.

Staines WA, Meister B, Melander T, Nagy Jl, Hökfelt T (1988) Threecolor immunofluorescence histochemistry allowing triple labeling within a single section. J Histochem Cytochem 36:145-151.

Tempel A, Zukin RS (1987) Neuroanatomical patterns of the mu, delta, and kappa opioid receptors of rat brain as determined by quantitative in vitro autoradiography. Proc Natl Acad Sci USA 84:4308-4312.

Thompson RC, Mansour A, Akil H, Watson SJ (1993) Cloning and 
pharmacological characterization of a rat mu opioid receptor. Neuron 11:903-913.

Thompson SM (1994) Modulation of inhibitory synaptic transmission in the hippocampus. In: Progress of neurobiology (Kerkut GA, Phillis JW, eds), pp 575-609. Oxford: Elsevier.

Vigna SR, Bowden JJ, McDonald DM, Fisher J, Okamoto A, McVey DC, Payan DG, Bunnett NW (1994) Characterization of antibodies to the rat substance $\mathrm{P}(\mathrm{NK}-1)$ receptor and to a chimeric substance $P$ receptor expressed in mammalian cells. J Neurosci 14:834-845.

von Zastrow M, Kobilka BK (1992) Ligand-regulated internalization and recycling of human beta 2-adrenergic receptors between the plasma membrane and endosomes containing transferrin receptors. J Biol Chem 267:3530-3538.

Wessendorf MW, Elde RP (1985) Characterization of an immunofluorescence technique for the demonstration of coexisting ncurotransmitters within nerve fibers and terminals. J Histochem Cytochem 33: 984-994.

Wessendorf MW, Apple NM, Molitor TW, Elde RP (1990) A method for immunofluorescent demonstration of threc cocxisting neurotransmitters in rat brain and spinal cord, using the fluorophores fluorescein, lissamine rhodamine, and 7-amino-4-methylcoumarin-3-acetic acid. J Histochem Cytochem 38:1859-1877.

Xie CW, Morrisett RA, Lewis DV (1992) Mu opioid receptor-mediated modulation of synaptic currents in dentate granule cells of rat hippocampus. J Neurophysiol 68:1113-1120.

Zajac JM, Lombard M-C, Peschanski M, Besson J-M, Roques BP (1989) Autoradiographic study of mu and delta opioid binding sites and neutral endopeptidase-24.11 in rat dorsal root rhizotomy. Brain Res 477:400-403.

Zhang X, Bao L, Xu Z-Q, Kopp J, Arvidsson U, Elde R, Hökfelt T (1994) Localization of NPY Y 1 receptors in the rat nervous system with special reference to somatic receptors on small DRG neurons. Proc Natl Acad Sci USA 91:11738-11742.

Zimprich A, Bacher B, Höllt V (1994) Cloning and expression of an isoform of the rat mu-opioid receptor ( $r \mu O R 1 B)$. Regul Pept 54:347348. 